\title{
Trapping, identification and rearing of edible palm weevils in Kenya and Uganda
}

\author{
J.P. Egonyu ${ }^{1 *}$ (D) K.J. Gitonga ${ }^{1}$, F.M. Khamis ${ }^{1}$, R.S. Copeland ${ }^{1}$, P. Finyange ${ }^{2}$, R. Odhiambo ${ }^{3}$, G. Ddamulira ${ }^{4}$, \\ C.M. Tanga ${ }^{1}$ and S. Subramanian ${ }^{1}$ \\ ${ }^{1}$ International Centre of Insect Physiology and Ecology, P.O. Box 30772-00100, Nairobi, Kenya; ${ }^{2}$ Kenya Agricultural and \\ Livestock Research Organization, Matuga, Kwale, 254, Kenya; ${ }^{3}$ Kenya Agricultural and Livestock Research Organization, \\ Alupe, Busia, 254, Kenya; ${ }^{4}$ National Crops Resources Research Institute, Namulonge, Wakiso, 256, Uganda; pegonyu@icipe.org
}

Received: 28 January 2021 / Accepted: 16 February 2021

(c) 2021 Wageningen Academic Publishers

OPEN ACCESS CC) (1) RESEARCH ARTICLE

\begin{abstract}
Palm weevils, Rhynchophorus spp. (Coleoptera: Curculionidae) double as devastating invasive pests of palms, and delicacies in many communities. This study evaluated ethyl acetate and 3-methyl-octan-4-ol for trapping palm weevils from coconut, oil and raffia palms in Kenya and Uganda; taking into account the distance of traps on oil palm from a forest or raffia palm. Eggs from the weevils from different locations were incubated and their larvae reared on sugarcane under laboratory conditions. All the 285 weevils collected were identified by morphological and molecular techniques as Rhynchophorus phoenicis, and the catch was female-biased. 3-methyl-octan-4-ol attracted more weevils than ethyl acetate. More weevils were caught at $\sim 100 \mathrm{~m}$ away from the forest than within $15 \mathrm{~m}$ outside the forest; and on raffia palm than oil palm irrespective of distance apart. Eggs took $\sim 4 \mathrm{~d}$ to develop and $95-100 \%$ of pupae developed into adults, irrespective of the collection site. Larval and pupal developmental periods for weevils from Uganda were longer than those of Kenya, resulting in egg-adult development of $\sim 6$ months and $\sim 4$ months, respectively. The sex ratio of laboratory produced males and females was similar. These results can guide in designing an integrated $R$. phoenicis management system with a dual benefit of protecting palms from weevil attack and utilising the weevils to improve human nutrition.
\end{abstract}

Keywords: 3-methyl-octan-4-ol, development, ethyl acetate, survival, Rhynchophorus phoenicis

\section{Introduction}

There are nine species of palm weevils, Rhynchophorus Herbst spp. (Coleoptera: Curculionidae) which are highly destructive invasive pests of palms and other plants worldwide (Giblin-Davis et al., 2013; Wattanapongsiri, 1966). Three species of these weevils are recorded in Africa namely Rhynchophorus phoenicis (Fabricius), Rhynchophorus quadrangulus Quedenfeldt and Rhynchophorus ferrugeneus (Olivier) (CABI, 2019; Chebbi, 2011; Giblin-Davis, 2001; Wattanapongsiri, 1966). R. phoenicis is a widely distributed and most destructive pest of oil palm (Elaeis guineensis Jaquin) and coconut palm (Cocos nucifera L.) in tropical Africa. On the other hand, R. quadrangulus occurs in WestCentral Africa; whereas R. ferrugeneus has been reported in five North African countries namely Algeria, Egypt, Libya, Morocco and Tunisia (CABI, 2019; Chebbi, 2011; Hill, 2008). Coconut palm is widespread in almost all tropical coastal areas of the world (Stauffer et al., 2014). It has been an important source of food, fibre, fuel, wine, water and other raw materials for communities in the East African coastline since its introduction by Asian traders in the late part of the first millennium (Boivin et al., 2013). Meanwhile, oil palm is indigenous to West Africa and the Congo Basin, but it has been introduced to more than 25 African countries as a plantation crop for palm oil, sauces, soap, wine, fertiliser (ashes), roofing (leaves), building material (trunk), medicines (roots) and other raw materials (Carrere, 2013; Stauffer et al., 2014). Raffia palm (Raphia spp.) have similar economic benefits as coconut and oil palms, and is an important host plant for the edible wild palm weevil larvae in Africa (Muafor et al., 2015; Obahiagbon, 2009).

Semiochemicals - organic compounds that mediate behavioural responses of organisms to their environment e.g. locating mates, hosts, or food sources, avoiding 
competition, escaping natural enemies, and overcoming natural defence systems of hosts - are widely applied in pest management programs as lures, repellents and mate disrupters (El-Shafie and Faleiro, 2017). These natural chemical signals are largely species specific and less persistent in the environment, therefore, they are harmless to non-target insects and do not pollute the environment. Some of the key drawbacks for the use of semiochemicals in pest management are their lower efficiency in eliminating pests compared to conventional insecticides, and expensive equipment needed for their extraction and characterisation. Male produced aggregation pheromones have been identified in seven species of Rhynchophorus weevils and applied in mass trapping and killing of the weevils in palm plantations (Gries et al., 1994; Jaffé et al., 1993; Oehlschlager, 2016; Weissling et al., 1993). The aggregation pheromones of these weevils comprise closely related methyl-branched secondary alcohols (Oehlschlager, 2016). Besides aggregation pheromones, several palm weevils such as R. phoenicis (Gries et al., 1994), R. ferrugeneus (AbdelAzim et al., 2017; Guarino et al., 2011), Rhynchophorus cruentatus (Giblin-Davis et al., 1994) and Rhynchophorus palmurum (Jaffé et al., 1993) are attracted to fermenting host plant odours. Ethyl acetate and ethyl propionate singly or jointly stand-out as the most commonly used palmderived lures which synergise aggregation pheromone of palm weevils (Abdel-Rahman et al., 2017; Giblin-Davis et al., 1994; Gries et al., 1994; Guarino et al., 2011; Jaffé et al., 1993; Oehlschlager, 2016). Therefore, these esters are suitable for detecting occurrence of different palm weevils in an area.

Some species of palm weevils such as $R$. phoenicis and $R$. ferrugeneus are delicacies in several communities across the world, especially in Asia and Africa where the larvae are valued at US\$ 7-12/kg (Anankware et al., 2016; Banjo et al., 2006; Cito et al., 2017; Hanboonsong et al., 2013; Meutchieye and Niassy, 2016). In Uganda, R. phoenicis is ranked the third most consumed insect after grasshoppers and termites (Okia et al., 2017). Palm weevil larvae may contain up to $72 \%$ fat and $41 \%$ crude protein (Mba et al., 2017; Quaye et al., 2018b; Rumpold and Schlüter, 2013); 714 $\mathrm{kcal} / 100 \mathrm{~g}$, and good amounts of all essential amino acids and fatty acids (Mba et al., 2017; Womeni et al., 2009, 2012). The weevil larvae are therefore nutritionally comparable or superior to conventional animal- and plant-protein sources (Kelemu et al., 2015; Raubenheimer and Rothman, 2013).

Traditional collectors of edible palm weevil larvae identify palm trees with symptoms of infestation and cut and split them up to extract the larvae (Muafor et al., 2015). This practice is destructive to the affected crops and unsustainable, hence necessitating development of a strategy of artificial rearing of the weevils to meet the demands of its consumers. Several studies have demonstrated that palm weevils can be reared on different artificial diets such as sugarcane and spoilt fruits like watermelon, pineapple and bananas (Bong et al., 2008; Giblin-Davis et al., 1989; Quaye et al., 2018a). However, obtaining stock colonies of adult weevils for rearing is still a challenge. Whereas traps baited with aggregation pheromones and fermenting palm volatiles laced with insecticides is a global strategy of managing palm weevils (Gries et al., 1994; Miguens et al., 2011; Nardi et al., 2011), the use of these traps to collect palm weevils for captive rearing to produce edible larvae has scarcely been explored. Palm weevil trapping, but without insecticides, could double as a pest management technique and a source of edible palm weevil larvae for improving nutrition and food security.

In this study, traps baited separately with ethyl acetate, a palm-derived attractant of different species of palm weevils, and 3-methyl-octan-4-ol, an aggregation pheromone of African palm weevil $R$. phoenicis, were evaluated for trapping palm weevils from different palm species in Kenya and Uganda for captive rearing. Our research hypotheses were: (1) diverse species of edible palm weevils occur at different sites on coconut and oil palms in Kenya, and raffia palm and oil palm in Uganda; (2) 3-methyl-octan-4-ol and ethyl acetate catch different quantities of palm weevils; (3) position of the baited traps on oil palms at different distances from a wild forest or raffia palm influences weevil catches; and (4) weevils collected from different sites have different developmental periods and survival rates during rearing in the laboratory.

\section{Materials and methods}

\section{Study sites}

The study was conducted in Kwale and Busia counties in Kenya; and Mayuge, Bugiri, Mukono, Masaka and Kalangala districts in Uganda. The geographical positioning system (GPS) data collected from the study sites were plotted on Arc Map using the Arc GIS software version 10.3 (Esri Eastern Africa Ltd, Nairobi, Kenya) (Figure 1). The sites were selected based on availability of palm weevil host plants. In Kenya, Kwale is among the major coconut palm production areas, involving largely small holder producers (Kadere $e t$ al., 2009; Odenya et al., 2006); whereas Busia is famous for oil palm production (Odenya et al., 2006). In Uganda, Mayuge, Bugiri, Mukono and Masaka districts have research adaptive oil palm trial farms sized 1-17 ha (Baguma et al., 2019); whereas Kalangala district has over 14,000 ha of oil palms (Carrere 2013; Vegetable Oil Development Project, 2016). Ages of the trees across sites were variable and not determined, as was the case with environmental conditions.

In Mukono district where the oil palm plantation was surrounded by a thick natural forest with undetermined plant species, the plantation was subdivided into two subsites, the peripheral zone within $15 \mathrm{~m}$ outside the forest, 

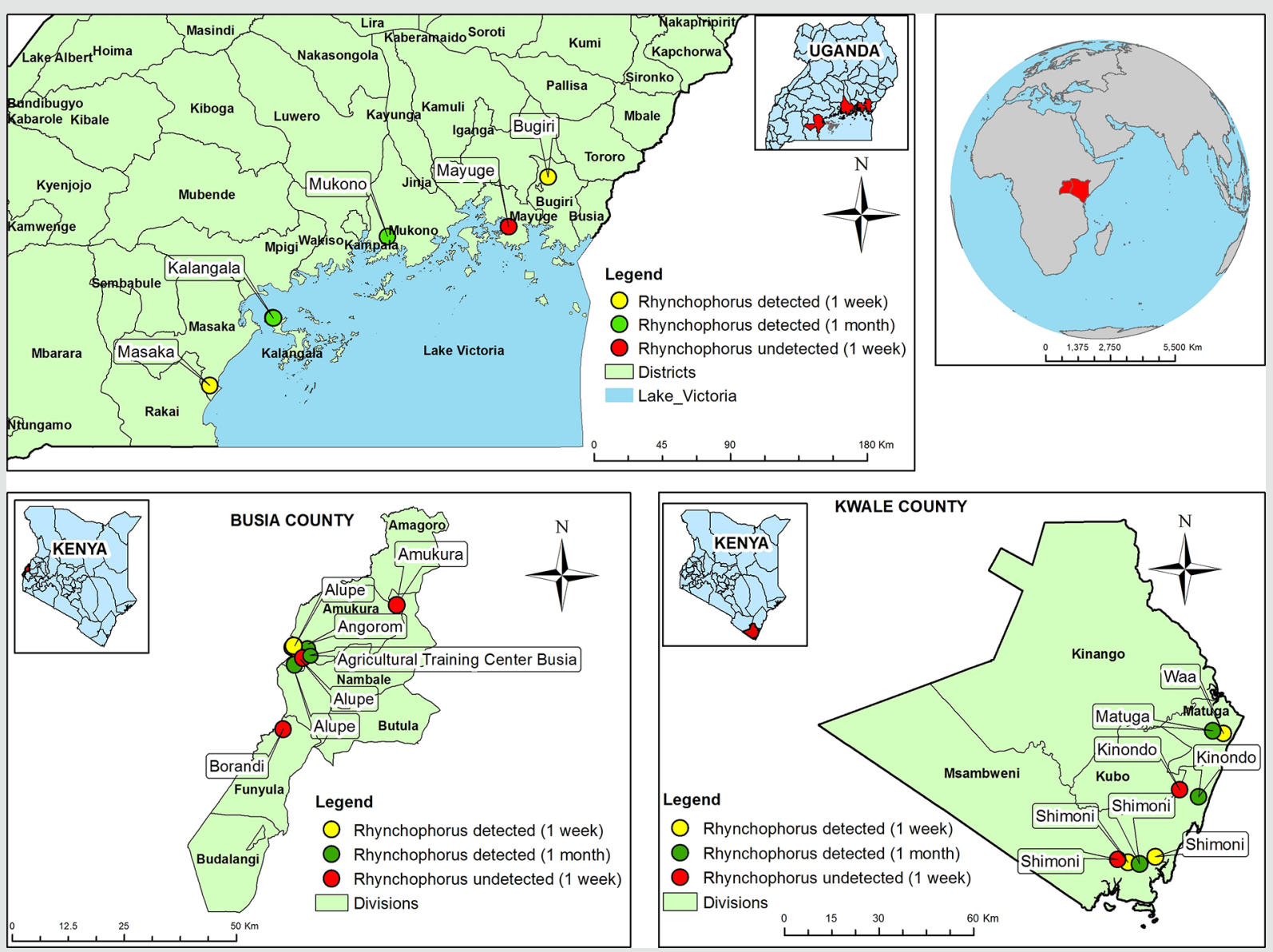

Figure 1. Sites where weevils were trapped from coconut, oil and raffia palms using 3-methyl-octan-4-ol and ethyl acetate in Kenya and Uganda during April to June 2019.

and the centre of the plantation, which was approximately $100 \mathrm{~m}$ away from the forest. This subdivision was guided by the report by Baguma et al. (2019) that the symptoms of R. phoenicis at this site were higher on oil palms positioned $100 \mathrm{~m}$ away from the forest than those within $15 \mathrm{~m}$ outside the forest. At Kalangala district, the study site comprised an oil palm plantation which was adjacent to wild raffia palms. The site was subdivided into: (1) the raffia palms; (2) the peripheral zone of oil palms, within $15 \mathrm{~m}$ from the raffia palm; and (3) oil palm trees approximately $100 \mathrm{~m}$ away from the raffia palms.

\section{Trap design and placement}

The lids of locally purchased 19 litre white plastic buckets were fitted with yellow modified unitrap tops (ChemTica Internacional S.A., Heredia, Costa Rica) using binding wires. The unitrap top funnels were designed to prevent escape of trapped adult weevils. Each trap was fitted with a hooked wire for holding the lure pouch approximately $2 \mathrm{~cm}$ below the lid of the bucket. Sugarcane stems which were purchased locally at each study site were cut into pieces of approximately $15 \mathrm{~cm}$ long and sliced longitudinally into two sub-equal halves. Eight sugarcane slices were placed in each bucket trap as a food bait to enhance attractiveness of the commercial lures. The traps were then tied to the trunks of the host plants (coconut, oil and raffia palms), $1.5-2 \mathrm{~m}$ above the ground.

\section{Lures}

Two pouched lures, P080-Lure ${ }^{ø}$ and P048-Lure ${ }^{\bullet}$, were purchased from ChemTica Internacional S.A. The P080Lure ${ }^{\circledR}$ was a kairomone containing $40 \mathrm{ml}$ of ethyl acetate, with a release rate of $200-400 \mathrm{mg} /$ day depending on ambient temperature. According to the manufacturer, this lure was designed to trap $R$. palmarum, $R$. ferrugeneus, $R$. cruentatus, Rhynchophorus bilineatus and R. phoenicis as well as Metamasius hemipterus. The broad-spectrum lure was therefore selected for detecting possible occurrence of these species in the study sites. On the other hand, P048-Lure contained 700-800 $\mathrm{mg}$ of the aggregation pheromone of $R$. phoenicis 'phoenicol' (3-methyl-octan-4-ol) (Gries et al., 1994; Perez et al., 1994), released at 3-10 mg/day. 


\section{Experimental design}

Preliminarily detection of sites infested with Rhynchophorus spp. for the one-month trapping experiment was carried out by placing 2-3 bucket traps baited separately with each lure at each site for 48-72 h. The red labels in Figure 1 show the sites where no Rhynchophorus spp. was caught. Based on the number of weevils caught (not shown) and logistical issues, Shimoni, Kinondo and Matuga in KwaleKenya; Alupe, Agriculture Training Centre and Angorom in Busia-Kenya; and Mukono and Kalangala districts in Uganda (labelled green in Figure 1) were selected for the month-long experiment. At Kwale-Kenya which was the first trapping site, two controls (unbaited trap and a trap baited with sugarcane only) were included. Unlike traps baited with the commercial lures, no Rhynchophorus spp. was caught in the control traps, therefore controls were excluded from subsequent trials.

At each trapping site in Kenya and subsites in Mukono and Kalangala districts in Uganda, 3-6 replicates of traps baited separately with either ethyl acetate or 3-methyloctan-4-ol were distributed at approximately $20 \mathrm{~m}$ apart in a completely randomised design. The traps were inspected weekly for four weeks to record the type and number of palm weevils caught. The study was conducted from $8^{\text {th }}$ April to $12^{\text {th }}$ May 2019 in Kwale; $13^{\text {th }}$ May to $16^{\text {th }}$ June 2019 in Busia; and 27 $7^{\text {th }}$ May to $30^{\text {th }}$ June 2019 in Uganda. Palm weevils recovered from the traps were sexed based on rostral setae that are only present in males (Giblin-Davis et al., 2013).

\section{Morphological identification of insects}

Samples of the palm weevils collected were morphologically identified according to the dichotomous keys published by Wattanapongsiri (1966), Arnett et al. (2002) and EPPO (2007). The identifications were confirmed by Salvatore Anzaldo from the School of Life Sciences, Arizona State University, USA. Voucher specimens of the weevils were deposited in the Biosystematics Support Unit collection of the International Centre of Insect Physiology and Ecology (icipe).

\section{Molecular identification of insects}

\section{DNA extraction and amplification}

Representative adult weevil samples from Kwale, Kenya, and Bugiri, Masaka and Kalangala districts in Uganda; and a larval sample from Kalangala were stored in $95 \%$ ethanol and transported to the Arthropod Pathology Unit at icipe. The right hind legs of representative adult samples and whole larval sample were each surface sterilised using $3 \% \mathrm{NaOCl}$ then rinsed thrice with distilled water. Genomic DNA was extracted from the individual legs using Isolate II Genomic DNA Kit (Bioline, London, United Kingdom), following the manufacturer's instructions. The resultant DNA was eluted in a final $50 \mu \mathrm{l}$ volume then quality and quantity checks done using the Nanodrop 2000/2000c Spectrophotometer (Thermo Fischer Scientific, Wilmington, DE, USA).

Polymerase chain reaction (PCR) was done to amplify the D2 region of 28S rDNA (28S) using Lep D2-Fw 5' AGTCGTGTTGCTTGATAGTGCAG 3' and Lep D2Rv 5' TTGGTCCGTGTTTCAAGACGGG 3' (Campbell et al., 1994; Goolsby et al., 2006) markers. The PCR was carried out in a total reaction volume of $20 \mu \mathrm{l}$ containing 5X My Taq Reaction Buffer (5 mM dNTPs, $15 \mathrm{mM} \mathrm{MgCl}_{2}$, stabilisers and enhancers), $0.5 \mathrm{pmol} / \mu \mathrm{l}$ of each primer, $0.5 \mathrm{mM} \mathrm{MgCl} 2,0.0625 \mathrm{U} / \mu \mathrm{l}$ My Taq DNA polymerase (Bioline) and $15 \mathrm{ng} / \mu \mathrm{l}$ of DNA template. This reaction was set up in the Nexus Mastercycler gradient (Eppendorf, Hamburg, Germany). The following cycling conditions were used: initial denaturation for $2 \mathrm{~min}$ at $95^{\circ} \mathrm{C}$, followed by 40 cycles of $30 \mathrm{~s}$ at $95^{\circ} \mathrm{C}, 30 \mathrm{~s}$ annealing at $58.8^{\circ} \mathrm{C}$ and $1 \mathrm{~min}$ at $72{ }^{\circ} \mathrm{C}$, then a final elongation step of $10 \mathrm{~min}$ at $72{ }^{\circ} \mathrm{C}$. The target gene region was approximately 575 base pairs.

The amplified PCR products were resolved through a $1.2 \%$ agarose gel. DNA bands on the gel were analysed and documented using KETA GL imaging system transilluminator (Wealtec Corp, Meadowvale Way Sparks, NV, USA). Successively amplified products were excised and purified using Isolate II PCR and Gel Kit (Bioline) following the manufacturer's instructions. The purified samples were shipped to Macrogen Inc. Europe Laboratory (Amsterdam, the Netherlands) for bi-directional sequencing.

\section{Sequences data analysis}

The successful sequences were assembled and edited using Geneious Version 8 (http://www.geneious.com) (Kearse et al., 2012). The primer sequences were identified and removed from the consensus sequences generated from both the forward and reverse reads. For conclusive identification of the species, similarity searches were conducted by querying the consensus sequences via Basic Local Alignment Search Tool (BLAST) at the GenBank database hosted by National Centre of Biotechnology Information (NCBI). BLAST algorithm finds regions of local similarity between sequences, in which consensus sequences were compared to reference sequences in the GenBank database. In addition, a query was done in Barcode of Life Database (BOLD). Sequences of the samples were then submitted to GenBank (Table 1).

\section{Development and survival of first generation of a laboratory colony of palm weevils}

Adult palm weevils collected from the different sites - two from Kenya separately (Kwale and Busia) and a combination for all samples from Uganda - were transported in ventilated 
Table 1. Molecular identification of samples collected from different locations in Kenya and Uganda.

$\begin{array}{lllll}\text { Locality } & \text { Collection point } & \text { GeneBank identity } & \text { ID \% } & \text { Sample accession number } \\ \text { Kwale-Kenya } & \mathrm{S} 04.15 .965^{\circ} ; \mathrm{E} 039.57507^{\circ} & \text { Rhynchophorus phoenicis } & 99.0 & \text { MW301383 } \\ \text { Kwale-Kenya } & \mathrm{S} 04.15 .965^{\circ} ; \mathrm{E} 039.57507^{\circ} & \text { R. phoenicis } & 98.9 & \mathrm{MW} 301382 \\ \text { Bugiri-Uganda } & \mathrm{N} 00^{\circ} 36.354 ; \mathrm{E} 033^{\circ} 44.353 & \text { R. phoenicis } & 97.1 & \mathrm{MW} 301385 \\ \text { Kalangala-Uganda } & \mathrm{S} 0013.857 ; \mathrm{E} 032.06 .725 & \text { R. phoenicis } & 95.0 & \mathrm{MW} 301381 \\ \text { Kalangala-Uganda } & \mathrm{S} 0013.857 ; \mathrm{E} 032.06 .725 & \text { R. phoenicis } & 97.1 & \mathrm{MW} 301386 \\ \text { Masaka-Uganda } & \mathrm{S} 00^{\circ} 37.870 ; \mathrm{E} 031^{\circ} 44.079 & \text { R. phoenicis } & 96.4 & \mathrm{MW} 301384\end{array}$

plastic containers measuring $15 \times 21 \mathrm{~cm}$ at the top, $12 \times 18$ $\mathrm{cm}$ at the bottom and $16 \mathrm{~cm}$ height (Kenpoly, Nairobi, Kenya) to icipe's Animal Rearing and Quarantine Unit. Ventilation was attained by puncturing small holes on the lids and sides of the containers with the tips of iron nails. The weevils were reared in these containers on sugarcane as food both in transit and in the insectary. The rearing room was maintained at $27.7 \pm 0.1{ }^{\circ} \mathrm{C}$ and $61.9 \pm 0.9 \% \mathrm{RH}$ with $12 \mathrm{~h}$ of light and $12 \mathrm{~h}$ of darkness. The choice of sugarcane as food for the weevils and the laboratory conditions were based on previous studies by Debrah (2016) and Quaye et al. (2018a). The sugarcane was replaced every two days during which the residues were incubated at ambient conditions of the rearing room. These residues were inspected daily to record incubation, larval and pupal durations. Only pupal survival rate was measured since eggs and larvae were concealed inside the rearing sugar cane. Adults were sexed as described above for field collected weevils.

\section{Data analysis}

Effects of type of lure and distance of traps from wild raffia palms $(0,15$ and $100 \mathrm{~m})$ or natural forest without raffia palms (within $15 \mathrm{~m}$ from the forest or $100 \mathrm{~m}$ away) on weevil catches at different sites; collection site on number of days of egg, larval, pupal and egg-adult development; and sex on egg-adult development were determined using generalised linear models (GLMs) with Poisson family and log link. The models were tested for goodness of fit by consideration of their dispersion parameters (i.e. ratio of residual deviance to degrees of freedom) which should be approximately one for a model to be considered fit (Breslow, 1996). Only dispersion parameters for GLMs fitted to data on developmental periods of eggs and pupae indicated proper fits, while models found to be unfit were corrected using negative binomial GLMs (Osgood, 2000), using the 'MASS' package (Ripley and Venables, 2002). There were no catches in traps baited with ethyl acetate in Busia and Mukono, therefore statistical comparisons of catches by type of lure were not carried out in these sites. The proportion of pupae that completed their respective stages were compared based on site of collection using the prop.test in $\mathrm{R}$ statistical computer software ( $\mathrm{R}$ Core Team, 2019). The percentage of male and female weevils from the field and the laboratory were also compared using the prop.test.

Where appropriate, means were separated using Tukey's multiple mean comparisons. The package 'effects' was used for generation of means (Fox and Weisberg, 2018); whereas 'multcomp' was used for mean separation (Hothorn et al., 2008). All analyses were carried out in $R$ version $R$ i386 3.5.3 (R Core Team, 2019), at $\alpha=0.05$.

\section{Results}

\section{Identification of insects trapped}

All collected adult palm weevil samples of undetermined ages were identified as $R$. phoenicis. The gene sequences of all samples analysed matched with those of $R$. phoenicis (GenBank accession number AY131091.1) by 95-99\% (Table 1).

\section{Catches of $R$. phoenicis in baited traps at different sites}

A total of 285 weevils were caught during the survey. About $55.1 \%$ of the catch were females, which was significantly higher than males $(44.9 \%)\left(\chi^{2}=10.5, \mathrm{df}=1, P=0.001\right)$. Traps baited with 3-methyl-octan-4-ol caught about 1-3 adult weevils per week in all the trial sites (Figure 2). Ethyl acetate baited traps caught the weevils in only Kwale and Kalangala, but their catches were significantly lower than those recorded for 3-methyl-octan-4-ol baited traps $\left(\chi^{2}=33.9\right.$; d.f. $=1 ; P<0.001$ and $\chi^{2}=33.5$; d.f. $=1 ; P<0.001$, respectively).

\section{Catches of $R$. phoenicis in traps placed on oil palms at the periphery and 100 metres away from the natural forest}

The mean catches of $R$. phoenicis on oil palms which were approximately $100 \mathrm{~m}$ away from the natural forest $(1.9 \pm 0.6$ weevils per trap per week) were significantly higher than the catches in traps placed at the periphery of the natural forest $(0.3 \pm 0.2)\left(\chi^{2}=6.5\right.$; d.f. $\left.=1 ; P=0.011\right)$. 


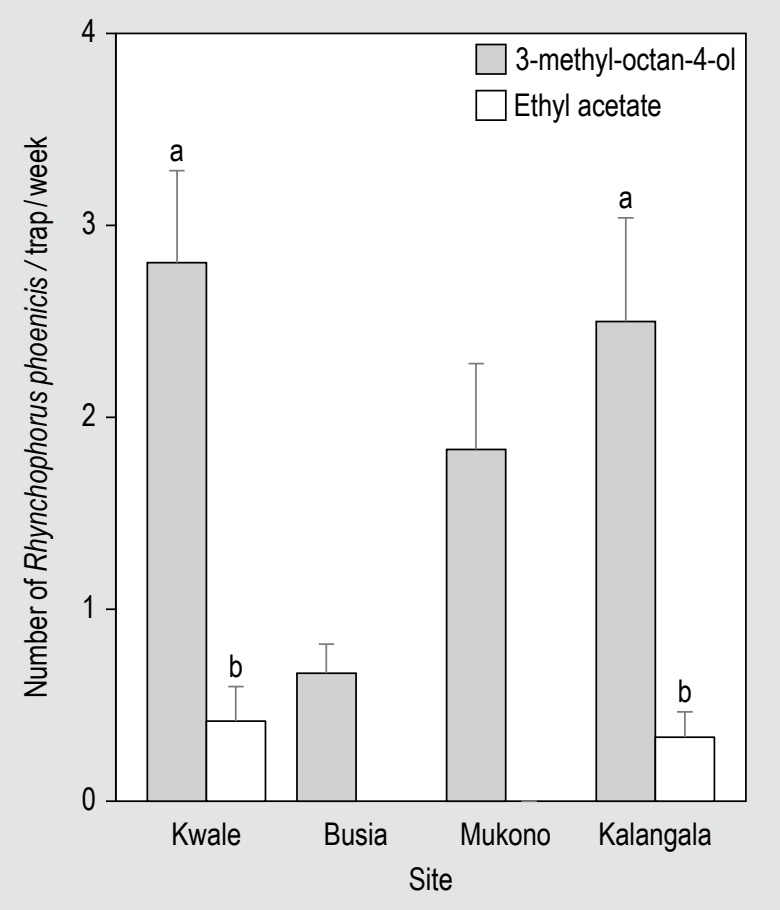

Figure 2. Mean numbers of Rhynchophorus phoenicis caught per week per trap baited with 3-methyl-octan-4-ol or ethyl acetate in Kenya (Kwale and Busia) and Uganda (Mukono and Kalangala) from April to June 2019. Error bars represent standard errors of means (SEM). Different letters on bars at Kwale and Kalangala indicate significant differences between the means.

\section{Catches of $R$. phoenicis in traps placed at different distances from the raffia palms}

Catches of $R$. phoenicis on traps tied to raffia palms were significantly higher than the catches from traps placed on oil palms at both $\leq 15 \mathrm{~m}$ and $100 \mathrm{~m}$ away from the raffia palms ( $\chi^{2}=15.3$; d.f. $=1 ; P<0.001$; Figure 3 ), but the weevil catches on oil palms at different distances from raffia palms were comparable.

\section{Development of first generation of a laboratory colony of $R$. phoenicis and survival of their pupae}

Larval hatch was first detected after about four days of egg incubation, irrespective of where the eggs were collected $\left(x^{2}=1.5\right.$; d.f. $=2 ; P=0.481$; Table 2$)$. However, larval, pupal and egg-adult developmental days for weevils collected from Uganda were significantly more than those of weevils collected from Kenya $\left(\chi^{2}=28.1\right.$; d.f. $=2 ; P<0.001, \chi^{2}=42.3$; d.f. $=2 ; P<0.001$ and $x^{2}=43.0$; d.f. $=2 ; P<0.001$, respectively). All pupae from Kenya, and $94.7 \%$ of those from Uganda successfully developed into adults, with no significant effect of collection site on pupal survival $\left(\chi^{2}=0.6\right.$; d.f. $\left.=2, P=0.741\right)$. Of the 29 adults that emerged, $58.6 \%$ were males while $41.4 \%$ were females, with no statistical difference in the percentage of the two sexes $\left(\chi^{2}=1.1, \mathrm{df}=1, P=0.294\right)$. There

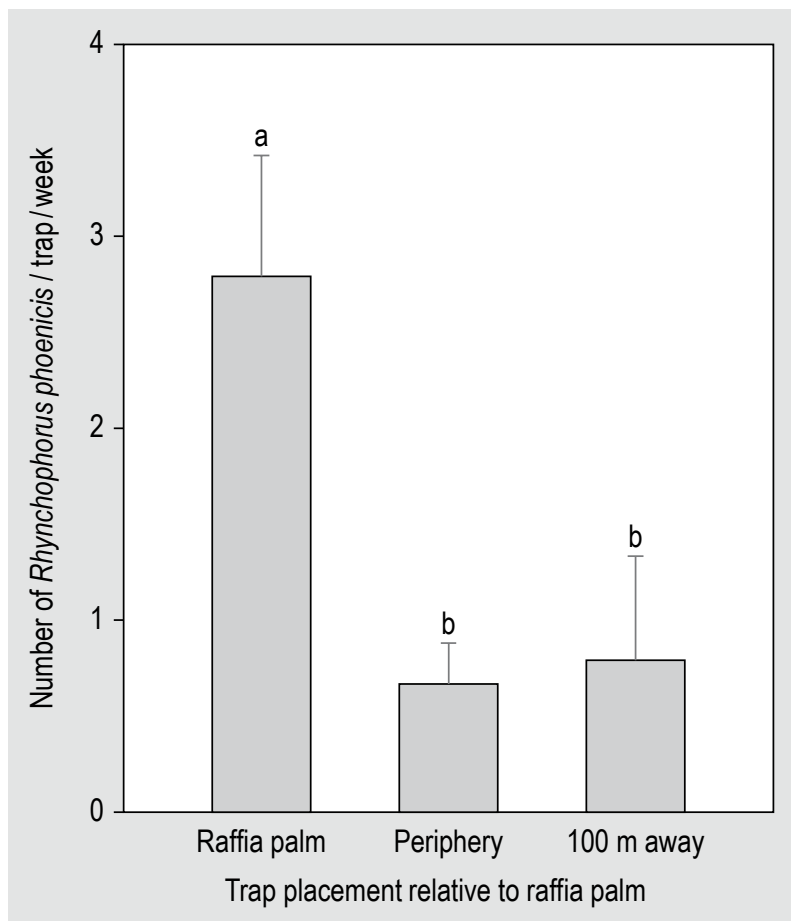

Figure 3. Mean number of Rhynchophorus phoenicis caught in traps placed on the wild raffia palms, and oil palms within $15 \mathrm{~m}$ and at $100 \mathrm{~m}$ away from the raffia palm from May to June 2019. Error bars represent SEM. Different letters on bars indicate significant differences between the means.

was no significant difference in egg-adult developmental days of males $(116.0 \pm 6.1 \mathrm{~d})$ and females $(129.0 \pm 11.0 \mathrm{~d})$ $\left(\chi^{2}=1.5 ;\right.$ d.f. $\left.=1 ; P=0.215\right)$.

\section{Discussion}

All palm weevils collected from oil, coconut and raffia palms in different sites in Uganda and Kenya were identified as R. phoenicis using both morphological and molecular techniques. We used the $28 \mathrm{~S}$ rDNA to characterise the insects collected from both countries to species level. This region is targeted for samples that are not successfully

Table 2. Mean ( \pm SEM) number of developmental days of different stages of Rhynchophorus phoenicis produced by adult weevils collected from Kenya and Uganda. ${ }^{1}$

$\begin{array}{lllll}\text { Site } & \text { Egg } & \text { Larva } & \text { Pupa } & \text { Egg-adult } \\ \text { Kwale-Kenya } & 4.3 \pm 0.4 \mathrm{a} & 78.0 \pm 4.7 \mathrm{a} & 35.2 \pm 1.7 \mathrm{a} & 113.4 \pm 4.5 \mathrm{a} \\ \text { Busia-Kenya } & 3.6 \pm 0.3 \mathrm{a} & 80.1 \pm 5.4 \mathrm{a} & 30.9 \pm 1.7 \mathrm{a} & 111.9 \pm 6.6 \mathrm{a} \\ \text { Uganda } & 4.3 \pm 0.4 \mathrm{a} & 142.8 \pm 19.3 \mathrm{~b} & 58.7 \pm 3.3 \mathrm{~b} & 194.3 \pm 13.4 \mathrm{~b}\end{array}$

${ }^{1}$ Different letters within a column indicate significant differences between the means. 
amplified using the classical barcoding markers such as the Folmer et al. (1994) primers. The molecular characterisation confirms the morphological identification and corroborates previous reports that $R$. phoenicis is widespread in tropical Africa (CABI, 2019). It seems therefore that the other two palm weevil species ( $R$. quadrangulus and $R$.ferrugeneus) reported in West-Central and North Africa, respectively (CABI, 2019; Chebbi, 2011; Hill, 2008), have not yet spread to Kenya and Uganda. Contrary to Baguma et al. (2019) who were unable to detect incidence of $R$. phoenicis in BugiriUganda, we recorded the presence of this species at this site. These discrepancies can be attributed to the methods used in sampling by the two studies, thus demonstrating the superiority of semiochemical lures in detecting occurrence of Rhynchophorus spp. over the use of host-plant infestation symptoms. A previous report shows that palm weevils can asymptomatically live cryptically inside palm trees for a long time (CABI, 2019).

The sex ratio of $R$. phoenicis adults caught in the survey was female biased. This finding is consistent with reports on other palm weevil species such as $R$. cruentatus (GiblinDavis et al., 1989; Weissling et al., 1993) and R. ferrugeneus (Abdel-Azim et al., 2017). Higher attraction of female palm weevils to semiochemicals lures than males could be attributed to higher sensitivity of female antennae to odours than those of males (Guarino et al., 2011). The higher catches of female than male $R$. phoenicis may be advantageous for obtaining more eggs for captive rearing, but it is necessary to determine the optimal sex ratio that meets the female mating needs.

Only traps baited with 3-methyl-octan-4-ol caught R. phoenicis in Busia and Mukono and approximately 7-8fold more weevils were trapped by this lure than ethyl acetate in Kwale and Kalangala. This finding concurs with the report by Rochat and Avand-Faghih (2000) that $R$. ferrugeneus was less attracted to date palm odour than its aggregation pheromone, 4-methyl-5-nonanol. However, Weissling et al. (1994) demonstrated that cabbage palmetto attracted more $R$. cruentatus than its aggregation pheromone, 5-methyl-4-octanol. This implies that sensitivity of palm weevils to host-derived volatiles compared to their aggregation pheromones depends on the species.

We established that traps placed on oil palms approximately $100 \mathrm{~m}$ away from the natural forest without raffia palms caught 6-fold more $R$. phoenicis than those at the periphery of the forest. This finding corroborates that of Baguma et al. (2019) who documented higher incidence of $R$. phoenicis symptoms on oil palms located $100 \mathrm{~m}$ away from the forest than those positioned at its periphery. Low pest density near undisturbed natural forest might be attributed to rich plant diversity with suitable microclimates which could boost the build-up of natural enemies of the pests
(Altieri, 1999; Letourneau et al., 2011). The rich plant diversity may also produce non-host volatiles that either repel the pests or mask host cues, thereby camouflaging the host plant (Andersson, 2007; Letourneau et al., 2011). Although damage by insect pests induces release of volatiles that attract natural enemies (Ahuja et al., 2011), such odours emanating from infested plants at a long distance from the forest may unfortunately not reach the natural enemies it harbours. Whereas literature on natural enemies of $R$. phoenicis is scarce (CABI, 2019), several parasitoids, predatory birds and entomopathogenic bacteria, fungi, viruses and nematodes have been reported to attack R. ferrugeneus in its native habitats in South East Asia (El-Shafie, 2014; Giblin-Davis et al., 2013). Further investigations are required to establish occurrence of natural enemies of $R$. phoenicis in East Africa for their potential integration into palm weevil biological control programs. Investigation of interaction of $R$. phoenicis with volatiles emanating from wild plants around oil palm plantations may help in identifying repellents which can be applied to deter the pest from the host plant.

Traps placed at the wild raffia palms caught 4-fold more $R$. phoenicis than traps placed on adjacent cultivated oil palms, irrespective of distance. This suggests that $R$. phoenicis prefers wild raffia palm to oil palm, and therefore it can be a potential trap crop (Piñero and Manandhar, 2015) which can lure away the pest from the oil palm (Cook et al., 2007; Eigenbrode et al., 2016). This finding also opens prospects for identification of more highly attractive host odor from raffia palm for optimising trapping of $R$. phoenicis.

Prior to this study, incubation periods of $R$. phoenicis eggs have been scarcely measured (Debrah, 2016; Quaye et al., 2018a; Wattanapongsiri, 1966). We found that $R$. phoenicis eggs developed in about four days, irrespective of the site of collection of the mother-weevils. This incubation period is closely similar to that of other palm weevils such as $R$. ferrugeneus, R. palmarum and R. vulneratus (GiblinDavis et al., 2013; Wattanapongsiri, 1966). Larvae and pupae produced by weevils collected from both Kwale and Busia in Kenya developed in approximately two and one months, respectively. However, the larval and pupal stages for samples originating from Uganda took approximately three and two months to develop, respectively. Overall, development of $R$. phoenicis samples from Kenya took about four months, while those from Uganda took more than six months. These observations contradict the reports by Wattanapongsiri (1966) that $R$. phoenicis pupal stage from unspecified location lasted for 26 days. Debrah (2016) also reported contrasting results that $R$. phoenicis larval and pupal stages developed for 20-39 d and 24-48 d, respectively, in Ghana. The differences demonstrated in the durations of development of $R$. phoenicis populations from different locations might be attributed to different factors such as genetic make of the different populations, geographical 
location, environmental conditions (especially temperatures and relative humidity) and probably the type of diet used (Boivin et al., 2004; Hamby et al., 2016).

This study revealed that approximately $95-100 \%$ of R. phoenicis pupae developed into adults irrespective of collection site, which closely corroborates the findings by Quaye et al. (2018a) in Ghana that $85-97 \%$ of $R$. phoenicis pupae survival to adulthood. We recorded comparable proportions of $R$. phoenicis males and females emerging from pupae, which concurs with the findings by Quaye et al. (2018a) when the weevils were reared on different diets in Ghana. This indicates that the sex ratio of natural populations of $R$. phoenicis is approximate $1: 1$, which may need to be maintained under artificial mass rearing conditions. More comprehensive investigations of survival of $R$. phoenicis through lifetable analysis would be helpful.

\section{Conclusion}

In conclusion, $R$. phoenicis is still the only species of palm weevils attacking different palm species in Kenya and Uganda. 3-Methyl-octan-4-ol was a more potent attractant of the palm weevils than ethyl acetate. The baited traps were more efficient in attracting female $R$. phoenicis than males. Plant diversity seems to play a critical role in repelling or regulating populations of $R$. phoenicis. This weevil appears to prefer raffia palm to oil palm, but the mechanism for this preference requires further investigation. Eggs from wild-collected R. phoenicis from Kenya and Uganda develop for about 4 days, but larval and pupal development was markedly influenced by country of origin, resulting in egg-adult development periods of $\sim 4$ months and over 6 months, respectively. Almost all pupal samples developed into adults, irrespective of the collection site. The ratio of male and female adults that emerged from the laboratory colony was approximately $1: 1$. These results are useful for designing an integrated $R$. phoenicis management system through trapping the weevils from infested palms for captive mass rearing to produce edible larvae. Future studies are necessary to establish the effect of environmental conditions on weevil catches and development.

\section{Acknowledgements}

We thank M. Miti, K. Ouma, F.L.O. Ombura, E. M. AbdelRahman, E. Kimani, V. Kerubo, D. Salifu, L. Alfonce, S. Ondiaka and F. W. Nyamu (International Centre of Insect Physiology and Ecology, icipe); G. Ddumba (National Coffee Research Institute, Mukono, Uganda); and A. Arimo (Kalangala Oil Palm Growers Trust (KOPGT, Uganda) for technical/field assistance. We appreciate the support from the managements of Kenya Agricultural and Livestock Research Organization (KALRO) Alupe, KALRO Matuga and KOPGT, Uganda during field work. We are grateful to Salvatore Anzaldo (Arizona State University) for confirmatory identification of the insects as Rhynchophorus phoenicis. We gratefully acknowledge the financial support for this research by the following organisations and agencies: The German Federal Ministry for Economic Cooperation and Development (BMZ) commissioned and administered through the Deutsche Gesellschaft für Internationale Zusammenarbeit (GIZ) Fund for International Agricultural Research (FIA), grant number: 012345678; BioInnovate Africa Programme Phase II through SIDA (INSBIZ Contribution ID No. 51050076); the Canadian International Development Research Centre (IDRC) and the Australian Centre for International Agricultural Research (ACIAR) (INSFEED - Phase 2: Cultivate Grant No: 108866-001); UK's Foreign, Commonwealth \& Development Office (FCDO); the Swedish International Development Cooperation Agency (Sida); the Swiss Agency for Development and Cooperation (SDC); the Federal Democratic Republic of Ethiopia; and the Government of the Republic of Kenya. The views expressed herein do not necessarily reflect the official opinion of the donors.

\section{Conflict of interest}

The authors declare that they have no conflict of interest.

\section{References}

Abdel-Azim, M.M., Aldosari, S.A., Mumtaz, R., Vidyasagar, P.S. and Shukla, P., 2017. Pheromone trapping system for Rhynchophorus ferrugineus in Saudi Arabia: optimization of trap contents and placement. Emirates Journal of Food and Agriculture 29: 936-948. https://doi.org/10.9755/ejfa.2017.v29.i12.1564

Abdel-Rahman, E.M., Landmann, T., Kyalo, R., Ong'amo, G., Mwalusepo, S., Sulieman, S. and Le Ru, B., 2017. Predicting stem borer density in maize using RapidEye data and generalized linear models. International Journal of Applied Earth Observation and Geoinformation 57: 61-74. https://doi.org/10.1016/j.jag.2016.12.008 Ahuja, I., Rohloff, J. and Bones, A.M., 2011. Defence mechanisms of Brassicaceae: implications for plant-insect interactions and potential for integrated pest management. Agronomy for Sustainable Development 30: 311-348. https://doi.org/10.1051/ agro/2009025

Altieri, M.A., 1999. The ecological role of biodiversity in agroecosystems. Agriculture, Ecosystems and Environment 74: 19-31. https://doi.org/10.1016/B978-0-444-50019-9.50005-4

Anankware, J.P., Osekre, E.A., Obeng-Ofori, D. and Khamala, C., 2016. Identification and classification of common edible insects in Ghana. International Journal of Entomology Research 1: 33-39.

Andersson, M., 2007. The effects of non-host volatiles on habitat location by phytophagous insects. Swedish University of Agricultural Sciences, Uppsala, Sweden, 38 pp.

Arnett, R.H., Thomas, M.C., Skelley, P.E. and Frank, J.H., 2002. American beetles. Polyphaga: Scarabaeoidea through Curculioninoidea. CRC Press, Boca Raton, FL, USA, 881 pp. 
Baguma, J., Otema, M., Ddamulira, G., Naluyimba, R. and Egonyu, J.P., 2019. Distribution and incidence of the oil palm weevil Rhynchophorus phoenicis (Fabricius, 1801) (Coleoptera: Curculionidae) in selected agro-ecological zones of Uganda. African Entomology 27: 477-487. https://doi.org/10.4001/003.027.0477

Banjo, A., Lawal, O. and Songonuga, E., 2006. The nutritional value of fourteen species of edible insects in southwestern Nigeria. African Journal of Biotechnology 5: 298-301.

Boivin, N., Crowther, A., Helm, R. and Fuller, D.Q., 2013. East Africa and Madagascar in the Indian Ocean world. Journal of World Prehistory 26: 213-281. https://doi.org/10.1007/s10963-013-9067-4

Boivin, T., Bouvier, J.C., Beslay, D. and Sauphanor, B., 2004. Variability in diapause propensity within populations of a temperate insect species: interactions between insecticide resistance genes and photoperiodism. Biological Journal of the Linnean Society 83: 341351. https://doi.org/10.1111/j.1095-8312.2004.00392.x

Bong, C.-F.J., Er, C.-C., Yiu, P.-H. and Rajan, A., 2008. Growth performance of the red-stripe weevil Rhynchophorus schach Oliv. (Insecta: Coleoptera: Curculionidae) on meridic diets. American Journal of Agricultural and Biological Sciences 3: 403-409.

Breslow, N.E., 1996. Generalized linear models: checking assumptions and strengthening conclusions. Statistica Applicata 8: 23-41.

CABI, 2019. Crop protection compendium. CABI, Wallingford, UK. Available at: https://bit.ly/2S1CvZI

Campbell, B.C., Steffen-Campbell, J.D. and Werren, J.H., 1994. Phylogeny of the Nasonia species complex (Hymenoptera: Pteromalidae) inferred from an internal transcribed spacer (ITS2) and 28S rDNA sequences. Insect Molecular Biology 2: 225-237.

Carrere, R., 2013. Oil palm in Africa: past, present and future scenarios. World Rainforest Movement, Montevideo, Uruguay, $111 \mathrm{pp}$.

Chebbi, H., 2011. First record of Rhynchophorus ferrugineus on Phoenix canariensis in Tunisia. Tunisian Journal of Plant Protection 6: 149153.

Cito, A., Longo, S., Mazza, G., Dreassi, E. and Francardi, V., 2017. Chemical evaluation of the Rhynchophorus ferrugineus larvae fed on different substrates as human food source. Food Science and Technology International 23: 529-539. https://doi. org/10.1177/1082013217705718

Cook, S.M., Khan, Z.R. and Pickett, J.A., 2007. The use of pushpull strategies in integrated pest management. Annual Review of Entomology 52: 375-400. https://doi.org/10.1146/annurev. ento.52.110405.091407

Debrah, S.K. 2016. Edible insect as a traditional food source among the Akans in Southern Ghana. MSc-thesis, University of Ghana, Accra, Ghana.

Eigenbrode, S.D., Birch, A.N.E., Lindzey, S., Meadow, R. and Snyder, W.E., 2016. A mechanistic framework to improve understanding and applications of push-pull systems in pest management. Journal of Applied Ecology 53: 202-212. https://doi.org/10.1111/13652664.12556

El-Shafie, H.A.F., 2014. Area-wide integrated management of red palm weevil, Rhynchophorus ferrugineus (Olivier 1790) (Coleoptera: Curculionidae) in date palm plantations: a review. Persian Gulf Crop Protection 3: 92-118.
El-Shafie, H.A.F. and Faleiro, J.R., 2017. Semiochemicals and their potential use in pest management. In: Shields, V. (ed.) Biological control of pest and vector insects. IntechOpen, London, UK.

European and Mediterranean Plant Protection Organization (EPPO), 2007. Rhynchophorus ferrugineus and Rhynchophorus palmarum. EPPO Bulletin 37: 571-579.

Folmer, O., Black, M., Hoeh, W., Lutz, R. and Vrijenhoek, R., 1994. DNA primers for amplification of mitochondrial cytochrome $\mathrm{c}$ oxidase subunit I from diverse metazoan invertebrates. Molecular Marine Biology and Biotechnology 3: 294-299.

Fox, J. and Weisberg, S., 2018. Visualizing fit and lack of fit in complex regression models with predictor effect plots and partial residuals. Journal of Statistical Software 87: 1-27. https://doi.org/10.18637/ jss.v087.i09

Giblin-Davis, R., 2001. Borers of palms. In: Howard, F., Moore, D., Giblin-Davis, R. and Abad, R. (eds.) Insects on palms. CABI Publishing, Wallingford, UK, pp. 267-304.

Giblin-Davis, R.M., Faleiro, J.R., Jacas, J.A., Peña, J.E. and Vidyasagar, P., 2013. Biology and management of the red palm weevil, Rhynchophorus ferrugineus. In: Peña, J. (ed.) Potential invasive pests of agricultural crops. CAB International, Wallingford, UK, pp. 1-34.

Giblin-Davis, R.M., Gerber, K. and Griffith, R., 1989. Laboratory rearing of Rhynchophorus cruentatus and R. palmarum (Coleoptera: Curculionidae). Florida Entomologist 72: 480-488.

Giblin-Davis, R.M., Weissling, T.J., Oehlschlager, A. and Gonzalez, L.M., 1994. Field response of Rhynchophorus cruentatus (Coleoptera: Curculionidae) to its aggregation pheromone and fermenting plant volatiles. Florida Entomologist 77: 164-177.

Goolsby, J.A., De Barro, P.J., Makinson, J.R., Pemberton, R.W., Hartley, D.M. and Frohlich, D.R., 2006. Matching the origin of an invasive weed for selection of a herbivore haplotype for a biological control programme. Molecular Ecology 15: 287-297.

Gries, G., Gries, R., Perez, A.L., Gonzales, L.M., Pierce, H.D., Oehlschlager, A.C., Rhainds, M., Zebeyou, M. and Kouame, B., 1994. Ethyl propionate: synergistic kairomone for African palm weevil, Rhynchophorus phoenicis L. (Coleoptera: Curculionidae). Journal of Chemical Ecology 20: 889-897. https://doi.org/10.1007/ BF02059585

Guarino, S., Bue, P.L., Peri, E. and Colazza, S., 2011. Responses of Rhynchophorus ferrugineus adults to selected synthetic palm esters: electroantennographic studies and trap catches in an urban environment. Pest Management Science 67: 77-81. https://doi. org/10.1002/ps.2035

Hamby, K.A., Bellamy, D.E., Chiu, J.C., Lee, J.C., Walton, V.M., Wiman, N.G., York, R.M. and Biondi, A., 2016. Biotic and abiotic factors impacting development, behavior, phenology, and reproductive biology of Drosophila suzukii. Journal of Pest Science 89: 605-619. https://doi.org/10.1007/s10340-016-0756-5

Hanboonsong, Y., Jamjanya, T. and Durst, P. B., 2013. Six-legged livestock: edible insect farming, collection and marketing in Thailand. FAO Regional Office for Asia and the Pacific, Bangkok, Thailand, 69 pp.

Hill, D.S., 2008. Pests of crops in warmer climates and their control. Springer Science \& Business Media, Cham, Switzerland, 708 pp. 
Hothorn, T., Bretz, F. and Westfall, P., 2008. Simultaneous inference in general parametric models. Biometrical Journal: Journal of Mathematical Methods in Biosciences 50: 346-363. https://doi. org/10.1002/bimj.200810425

Jaffé, K., Sánchez, P., Cerda, H., Hernández, J., Jaffé, R., Urdaneta, N., Guerra, G., Martínez, R. and Miras, B., 1993. Chemical ecology of the palm weevil Rhynchophorus palmarum (L.) (Coleoptera: Curculionidae): attraction to host plants and to a male-produced aggregation pheromone. Journal of Chemical Ecology 19: 1703-1720. https://doi.org/10.1007/BF00982302

Kadere, T., Oniango, R., Kutima, P. and Njoroge, S., 2009. Production, marketing and economic importance of mnazi and other coconutbased products in Kenya. Research Journal of Agriculture and Biological Sciences 5: 815-822.

Kearse, M., Moir, R., Wilson, A., Stones-Havas, S., Cheung, M., Sturrock, S., Buxton, S., Cooper, A., Markowitz, S. and Duran, C., 2012. Geneious basic: an integrated and extendable desktop software platform for the organization and analysis of sequence data. Bioinformatics 28: 1647-1649. https://doi.org/10.1093/ bioinformatics/bts199

Kelemu, S., Niassy, S., Torto, B., Fiaboe, K., Affognon, H., Tonnang, H., Maniania, N. and Ekesi, S., 2015. African edible insects for food and feed: inventory, diversity, commonalities and contribution to food security. Journal of Insects as Food and Feed 1: 103-119. https:// doi.org/10.3920/JIFF2014.0016

Letourneau, D.K., Armbrecht, I., Rivera, B.S., Lerma, J.M., Carmona, E.J., Daza, M.C., Escobar, S., Galindo, V., Gutiérrez, C. and López, S.D., 2011. Does plant diversity benefit agroecosystems? A synthetic review. Ecological Applications 21: 9-21. https://doi.org/10.1890/092026.1

Mba, A.R.F., Kansci, G., Viau, M., Hafnaoui, N., Meynier, A., Demmano, G. and Genot, C., 2017. Lipid and amino acid profiles support the potential of Rhynchophorus phoenicis larvae for human nutrition. Journal of Food Composition and Analysis 60: 64-73. https://doi. org/10.1016/j.jfca.2017.03.016

Meutchieye, F. and Niassy, S., 2016. Preliminary observations on the commercialisation of Rynchophorus phoenicis larvae at Mvog-Mbi market in Yaoundé, Cameroon. Journal of Insects as Food and Feed 2: 199-202. https://doi.org/10.3920/JIFF2015.0081

Miguens, F.C., De Magalhães, J.A.S., De Amorim, L.M., Goebel, V.R., Le Coustour, N., Lummerzheim, M., Moura, J.I.L. and Costa, R.M., 2011. Mass trapping and biological control of Rhynchophorus palmarum L.: a hypothesis based on morphological evidences. EntomoBrasilis 4: 49-55.

Muafor, F.J., Gnetegha, A.A., Le Gall, P. and Levang, P., 2015. Exploitation, trade and farming of palm weevil grubs in Cameroon. Center for International Forestry Research, Bogor, Indonesia, 44 pp.

Nardi, S., Ricci, E., Lozzi, R., Marozzi, F., Ladurner, E., Chiabrando, F., Granchelli, L., Verdolini, E., Isidoro, N. and Riolo, P., 2011. Control of Rhynchophorus ferrugineus (Olivier, 1790) according to EU Decision 2007/365/EC in the Marche region (Central-Eastern Italy). EPPO Bulletin 41: 103-115. https://doi.org/10.1111/j.13652338.2011.02459.x

Obahiagbon, F., 2009. A review of the origin, morphology, cultivation, economic products, health and physiological implications of raphia palm. African Journal of Food Science 3: 447-453.
Odenya, O., Mambiri, G. and Rachier, G., 2006. Baseline survey on oil palm production in Western Kenya. Kenya Agricultural Research Institute, Nairobi, Kenya. Available at: https://bit.ly/2wM4wMB

Oehlschlager, A., 2016. Palm weevil pheromones-discovery and use. Journal of Chemical Ecology 42: 617-630. https://doi.org/10.1007/ s10886-016-0720-0

Okia, C., Odongo, W., Nzabamwita, P., Ndimubandi, J., Nalika, N. and Nyeko, P., 2017. Local knowledge and practices on use and management of edible insects in Lake Victoria basin, East Africa. Journal of Insects as Food and Feed 3: 83-93. https://doi.org/10.3920/ JIFF2016.0051

Osgood, D.W., 2000. Poisson-based regression analysis of aggregate crime rates. Journal of Quantitative Criminology 16: 21-43. https:// doi.org/10.1023/A:1007521427059

Perez, A.L., Gries, G., Gries, R., Giblin-Davis, R.M. and Oehlschlager, A.C., 1994. Pheromone chirality of African palm weevil, Rhynchophorus phoenicis (F.) and palmetto weevil, Rhynchophorus cruentatus (F.) (Coleoptera: Curculionidae). Journal of Chemical Ecology 20: 2653-2671. https://doi.org/10.1007/BF02036199

Piñero, J.C. and Manandhar, R., 2015. Effects of increased crop diversity using trap crops, flowering plants, and living mulches on vegetable insect pests. Trends in Entomology 11: 91-109.

Quaye, B., Atuahene, C.C., Donkoh, A., Adjei, B.M., Opoku, O. and Amankrah, M.A., 2018a. Alternative feed resource for growing african palm weevil (Rhynchophorus phoenicis) larvae in commercial production. American Scientific Research Journal for Engineering, Technology, and Sciences 48: 36-44.

Quaye, B., Atuahene, C.C., Donkoh, A., Adjei, B.M., Opoku, O. and Amankrah, M.A., 2018b. Nutritional potential and microbial status of african palm weevil (Rhynchophorus phoenicis) larvae raised on alternative feed resources. American Scientific Research Journal for Engineering, Technology, and Sciences 48: 45-52.

R Core Team, 2019. R: a language and environment for statistical computing. R Foundation for Statistical Computing, Vienna, Austria.

Raubenheimer, D. and Rothman, J.M., 2013. Nutritional ecology of entomophagy in humans and other primates. Annual Review of Entomology 58: 141-160. https://doi.org/10.1146/annurevento-120710-100713

Ripley, B.D. and Venables, W., 2002. Modern applied statistics with S. Springer, New York, NY, USA, 512 pp.

Rochat, D. and Avand-Faghih, A., 2000. Trapping of red palm weevil (Rhynchophorus ferrugineus) in Iran with selective attractants. In: Kleeberg H. and Zebitz C.P.W. (eds) Practice oriented results on use and production of neem-ingredients and pheromones. Druck \& Graphic, Giessen, Germany, pp. 219-224.

Rumpold, B.A. and Schlüter, O.K., 2013. Nutritional composition and safety aspects of edible insects. Molecular Nutrition and Food Research 57: 802-823. https://doi.org/10.1002/mnfr.201200735

Stauffer, F.W., Ouattara, D. and Stork, A.L., 2014. Palmae (Arecaceae). In: Lebrun, J.P. and Stork, A.L. (eds.) Tropical African flowering plants: monocotyledons. Conservatoire et Jardin botaniques de la Ville de Genève, Switzerland, pp. 326-354.

Vegetable Oil Development Project, 2016. Republic of Uganda, vegetable oil development project - phase 2 (VODP2) supervision report. Available at: https://bit.ly/383WTz3 
Wattanapongsiri, A., 1966. A revision to the genera Rhynchophorus and Dynamis (Coleoptera: Curculionidae). PhD-thesis, Oregon State University, Corvallis, OR, USA.

Weissling, T.J., Giblin-Davis, R.M., Gries, G., Gries, R., Pérez, A.L., Pierce, H. and Oehlschlager, A.C., 1994. Aggregation pheromone of palmetto weevil, Rhynchophorus cruentatus (F.) (Coleoptera: Curculionidae). Journal of Chemical Ecology 20: 505-515. https:// doi.org/10.1007/BF02059593

Weissling, T.J., Giblin-Davis, R.M. and Scheffrahn, R.H., 1993. Laboratory and field evidence for maleproduced aggregation pheromone in Rhynchophorus cruentatus (F.) (Coleoptera: Curculionidae). Journal of Chemical Ecology 19: 1195-1203. https://doi. org/10.1007/BF02059593
Womeni, H.M., Linder, M., Tiencheu, B., Mbiapo, F.T., Villeneuve, P., Fanni, J. and Parmentier, M., 2009. Oils of insects and larvae consumed in Africa: potential sources of polyunsaturated fatty acids. Oléagineux, Corps gras, Lipides 16: 230-235. https://doi. org/10.1051/ocl.2009.0279

Womeni, H.M., Tiencheu, B., Linder, M., Nabayo, C., Martial, E., Tenyang, N., Tchouanguep Mbiapo, F., Villeneuve, P., Fanni, J. and Parmentier, M., 2012. Nutritional value and effect of cooking, drying and storage process on some functional properties of Rhynchophorus phoenicis. International Journal of Life Science and Pharma Research 2: 203-219. 
